\title{
Value-conflicts in the conservation of a native species: a case study based on the endangered white-clawed crayfish in Europe
}

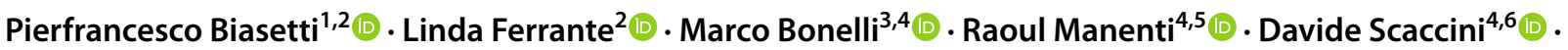 \\ Barbara de Mori $^{2,7}$ (D)
}

Received: 14 December 2020 / Accepted: 23 March 2021 / Published online: 11 May 2021

(c) The Author(s) 2021

\begin{abstract}
The future of the native European crayfish Austropotamobius pallipes depends on accurate conservation management. The goal of this paper is to attempt an investigation of the major ethical conflicts that can emerge in the conservation of this endangered crayfish threatened by invasive competitors, introduced diseases, and landscape alteration. To assess this issue, we will employ the Ethical Matrix, in a version explicitly tailored for its use in conservation. The filled Ethical Matrix will highlight several potential conflicts between values such as environmental protection, social and economic interests, animal welfare, cultural and aesthetic value, etc. We will discuss these conflicts, alongside some potential mitigating strategies present in the literature. We will stress in particular the need to take into account the ethical principle of fairness when assessing the economic and recreational value of invasive species, especially concerning the unfair distribution of costs. Moreover, we will assert the importance of conservation of $A$. pallipes both for its existence value and for its role as an umbrella and keystone species. Beyond its focus on A. pallipes, the Ethical Matrix here discussed might also provide insights on the value conflicts relative to analogous in situ conservation efforts involving a native species threatened by invasive alien competitors.
\end{abstract}

Pierfrancesco Biasetti

biasetti@izw-berlin.de

1 Department of Reproduction Management, Leibniz Institute for Zoo and Wildlife Research, Alfred Kowalke Straße 117, 10315 Berlin, Germany

2 Ethics Laboratory for Veterinary Medicine, Conservation and Animal Welfare, University of Padua, viale dell’Università 16, Agripolis, 35020 Legnaro, PD, Italy

3 Department of Biosciences, University of Milan, via Celoria 26, 20133 Milan, Italy

4 Associazione WWF Lecco, Località Camporeso, 23851 Galbiate, LC, Italy

5 Department of Environmental Science and Policy, University of Milan, via Celoria 10, 20133 Milan, Italy

6 Department of Agronomy, Food, Natural Resources, Animals and Environment, University of Padua, viale dell'Università 16, Agripolis, 35020 Legnaro, PD, Italy

7 Department of Comparative Biomedicine and Food Science, University of Padua, viale dell'Università 16, Agripolis, 35020 Legnaro, PD, Italy 


\section{Graphic abstract}
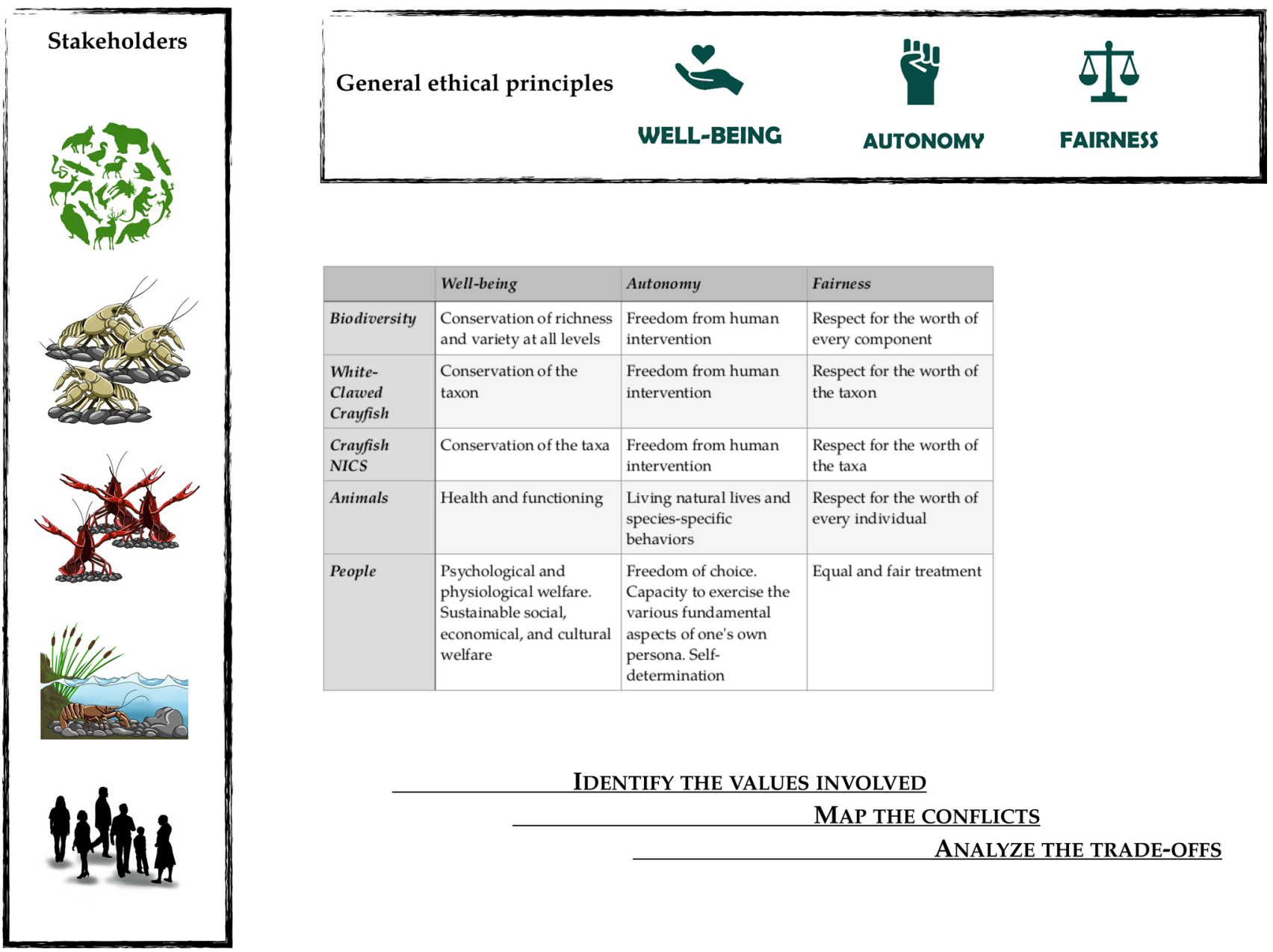

\begin{tabular}{|c|c|c|c|}
\hline & Well-being & Autonomy & Fairness \\
\hline Biodiversity & $\begin{array}{l}\text { Conservation of richness } \\
\text { and variety at all levels }\end{array}$ & $\begin{array}{l}\text { Freedom from human } \\
\text { intervention }\end{array}$ & $\begin{array}{l}\text { Respect for the worth of } \\
\text { every component }\end{array}$ \\
\hline $\begin{array}{l}\text { White- } \\
\text { Clawed } \\
\text { Crayfish }\end{array}$ & $\begin{array}{l}\text { Conservation of the } \\
\text { taxon }\end{array}$ & $\begin{array}{l}\text { Freedom from human } \\
\text { intervention }\end{array}$ & $\begin{array}{l}\text { Respect for the worth of } \\
\text { the taxon }\end{array}$ \\
\hline $\begin{array}{l}\text { Crayfish } \\
\text { NICS }\end{array}$ & Conservation of the taxa & $\begin{array}{l}\text { Freedom from human } \\
\text { intervention }\end{array}$ & $\begin{array}{l}\text { Respect for the worth of } \\
\text { the taxa }\end{array}$ \\
\hline Animals & Health and functioning & $\begin{array}{l}\text { Living natural lives and } \\
\text { species-specific } \\
\text { behaviors }\end{array}$ & $\begin{array}{l}\text { Respect for the worth of } \\
\text { every individual }\end{array}$ \\
\hline People & $\begin{array}{l}\text { Psychological and } \\
\text { physiological welfare. } \\
\text { Sustainable social, } \\
\text { economical, and cultural } \\
\text { welfare }\end{array}$ & $\begin{array}{l}\text { Freedom of choice. } \\
\text { Capacity to exercise the } \\
\text { various fundamental } \\
\text { aspects of one's own } \\
\text { persona. Self- } \\
\text { determination }\end{array}$ & Equal and fair treatmen \\
\hline
\end{tabular}

Keywords Austropotamobius pallipes · Conflicts in conservation · Conservation ethics · Crayfish · Ethical matrix

\section{Introduction}

Europe hosts several species of freshwater crayfishes (Decapoda: Astacidae), including at least six native species (Astacus astacus, A. leptodactylus, A. pachypus, Austropotamobius pallipes, $A$. torrentium, and A. bihariensis), three non-indigenous crayfish species (NICS) introduced before 1975 from North America (Faxonius limosus, Pacifastacus leniusculus, and Procambarus clarkii), and at least eight recently introduced NICS from North America and Australia (Cherax destructor, C. quadricarinatus, Faxonius immunis, $F$. juvenilis, $F$. virilis, Procambarus cf. acutus, P. virginalis, and $P$. alleni) - these latter usually found only in small wild populations, or as single released individuals (Holdich et al. 2009a; Kouba et al. 2014).

Most NICS show traits like high fecundity, rapid growth, high dispersal ability, opportunistic diet, tolerance of a wide range of environmental conditions, and can be classified as invasive alien species (IAS) as they can negatively impact biodiversity and human interests, by out-competing native species, modifying habitats and ecosystems, and spreading diseases and parasites. Species-specific assessment of invasiveness of NICS varies between "very high" $(P$. clarkii and $P$. leniusculus), "high" (F. immunis, F. limosus, F. virilis, $P$. cf. acutus, $C$. destructor) and "medium" (C. quadricarinatus, $P$. virginalis) ranges (Tricarico et al. 2010). F. limosus, $P$. leniusculus, $P$. clarkii, $F$. virilis, and $P$. virginalis are included in the EU List of Invasive Alien Species of Union concern, and are subjected to EU Regulation no.1143/2014.

While NICS thrive in most of their new non-native areal, European indigenous crayfish species (ICS) are, by large, declining. Currently, only A. leptodactylus is assessed by IUCN as of "Least Concern" (Gherardi and Souty-Grosset 2017a), and it is worth noting that in some European 
countries-like, for instance, Italy-it is an introduced species, with a "medium" invasiveness score (Tricarico et al. 2010). A. pachypus is classified "Data Deficient" (Gherardi and Souty-Grosset 2017b), as is the stone crayfish A. torrentium, whose population trend is, however, registered as decreasing (Füreder et al. 2010a). The noble crayfish $A$. astacus is classified as "Vulnerable" with a decreasing population (Edsman et al. 2010), while the white-clawed crayfish A. pallipes is "Endangered" (Füreder et al. 2010b). The reasons for the decline of native European crayfish species are multifaceted, but can be traced back to human-induced causes - the most relevant being the introduction of competitor NICS, which are moreover vectors of the crayfish plague Aphanomyces astaci (Souty-Grosset et al. 2016; Svoboda et al. 2017), urban and agricultural development, pollution, and introduction of non-indigenous predators.

Austropotamobius pallipes seems to be particularly at disadvantage in the current situation. In relation to other freshwater crayfishes, A. pallipes shows many biological characteristics typical of $\mathrm{K}$-selected species, such as slowgrowth rate, long average life span, late sexual maturity, low fertility, and significant maternal care (Aquiloni et al. 2010). This makes it particularly vulnerable to habitat instabilities and modifications, in particular when competitor r-specieslike, for instance, the red swamp crayfish $P$. clarkii (Gherardi 2006) — are present. A. pallipes was first classified as "Vulnerable" in 1996, and has shown since a major decline in all Europe, except Ireland (Füreder et al. 2010b; McFarlane et al. 2019). In Italy, for instance, where it is the most widespread ICS, this decline has been regularly documented during in the last years (Füreder et al. 2002, 2003; Nardi et al. 2005; Renai et al. 2006; Tirelli et al. 2008; Scalici et al. 2009; Mazza et al. 2011; Bonelli et al. 2017; Manenti et al. 2019a).

A major reason for the demise of A. pallipes has been the so-called "crayfish plague", whose etiological agent is the oomycete A. astaci. The first alleged occurrence of crayfish plague in Europe is registered in 1859-in Italy-and coincided with a major collapse of ICS (Cornalia 1860; Martinati 1861; Ninni 1865; Alderman 1996). The spreading of the crayfish plague was favored by the introduction of NICS in Europe. It was unknown at the time that the species imported to restock the crayfish population, as much as they were resistant to the crayfish plague, were also primary vectors for its spread (Holdich et al. 2009a). There has been some evidence that specific strains of $A$. astaci-probably those descending from the very first outbreak-may be less aggressive (Caprioli et al. 2013), but, after more than a hundred and half years after its appearance in Europe, only extremely sporadic resistance to the crayfish plague has been reported in ICS (Martín-Torrijos et al. 2017).

The introduction of non-indigenous predators represents an additional threat to this species. The American mink
(Neovison vison), for instance, is a known predator of $A$. pallipes (Smal 1991; Mezzetto et al 2021), and its negative effects on ICS populations have been well documented (Fischer et al. 2009). The northern raccoon (Procyon lotor) also poses a documented threat to A. pallipes, acting as a predator of the native species (Boscherini et al. 2019; Boncompagni et al. 2021).

While the introduction of competitor NICS, alien diseases, and non-indigenous predators can be counted as indirect human-caused sources for the decline of $\mathrm{A}$. pallipes, other extinction drivers are more directly connected with humans' actions. Water abstraction for use in intensive agriculture is perhaps the most important (Aquiloni et al. 2010). In fact, when combined with climate change-induced droughts (Marchina et al. 2017), water abstraction severely reduces the number of suitable habitats, by fragmenting and even completely drying streams and rivers during the summer (Nardi et al. 2005). Channelization of banks and destruction of riparian vegetation along riverbeds are other major negative habitat modifications, as they remove food sources and shelters, and raise the water temperature during summer (Gherardi et al. 2004; Brusconi et al. 2008; Benvenuto et al. 2008). Moreover, poaching of A. pallipes, which is still present for mainly traditional value, is a further source of stress for populations already fragmented and hence numerically and genetically depleted (Renai et al. 2006; Aquiloni et al. 2010; Mazza et al. 2011).

For all these reasons, the future of A. pallipes depends on accurate conservation plans and management. The goal of this paper is to attempt an investigation of the major ethical and value-conflicts that can emerge in the conservation management of the white-clawed crayfish. As conservation projects can affect multiple value dimensions (such as environmental protection, social and economic interests, animal welfare, cultural and aesthetic value, etc.), conflicts are a constant of most decision-making processes in conservation. The aim is to provide decision-makers with a framework of the possible issues - from an ethical and value-perspectiveinvolved in the conservation of A. pallipes. To do so, we will employ an analytical tool called the Ethical Matrix (Mepham 1996 - henceforth: EM), in a version explicitly tailored for use in conservation (Biasetti and de Mori 2019, 2021; Biasetti et al. 2020).

The EM provided in this paper should recap all the ethically relevant aspects involved. This may become important during the decision-making process as some kinds of value-such as the existence or heritage value of a species involved - are hard to quantify, and often end up being overlooked when trade-off are discussed and proposed (Law et al. 2018). Moreover, the EM could help with conflictsresolution. In particular, the application of the EM should not only help decision-makers to investigate the various angles involved and the reasons that support them, but also 
provide a way to analyze and weigh the arguments for or against certain policies from an ethical perspective. This perspective, by adding further elements to the debate based on generally recognized ethical principles, could strengthen certain arguments in favor of conservation.

\section{Filling the EM}

The Ethical Matrix (EM) is a conceptual tool devised to unpack and highlight all the value-demands involved in a complex scenario, allowing decision-makers to assess the impact of specific choices on the different stakeholders and to map the potential value-conflicts. An EM does not provide conclusions concerning the "right" choice but can be used for situation analysis, building decision trees, charting the consequences of decisions, and evaluate possible trade-offs.

Visually, the EM is a table made up of intersecting rows and columns. Cells from the first column list stakeholders. Cells from the first-row list general ethical principles-particularly influential, recognized, and shared abstract tenets of ethical reasoning such as well-being, autonomy, and fairness. Every other cell is filled with the specific valuedemands that may be advanced by (or for) the stakeholders on the ground of the general ethical principles. It is important to note that value-demands are by no means absolute or mandatory: they are, instead, prima facie-meaning with this technical expression that they can be downsized, revised, or superseded during a balancing process involving other prima facie demands.

EMs can be filled in three ways. They can be filled topdown by ethical experts, otherwise, they can be filled bottom-up by practitioners using their "hands-on" experience. A third option is to combine these two approaches, starting top-down and refining bottom-up, or vice versa. The EM described in this article has been compiled adopting a top-down approach with the general intent of providing a starting-point for bottom-up revisions. The available literature on the subject was used to reach significant conclusions in the application of the general principles to the stakeholders. The main goal of the EM presented here is to provide a general framework that could be adopted as a starting point to describe more specific cases involving A. pallipes. Moreover, beyond cases involving $A$. pallipes, this EM might also provide insights on the value and ethical conflicts relative to analogous in situ conservation efforts involving a native species threatened by the presence of IAS competitors.

Five stakeholders were identified for this EM: (1) the white-clawed crayfish, considered as the main object of the conservation efforts analyzed here in abstract; (2) NICS, which-either directly (by exercising dominance) or indirectly (as carriers of $A$. astaci, or by occupying ecological niches thus preventing re-colonization)—can successfully compete with A. pallipes; (3) biodiversity, understood as the biological richness and variety at all levels (genes, species, interactions, processes, etc.); (4) individual crayfish, whatever their species is, as living beings; (5) people, understood as all the human beings living, working, studying, visiting or simply interested in the area where the conservation efforts are taking place.

These stakeholders pertain to three different classes of entities, each tied to a different value dimension. The first three stakeholders-A. pallipes, NICS, and biodiversitypertains to the class of biotic entities, tied to the value dimension of environmental conservation. The fourth stakeholder-individual crayfish-pertains to the class of animals, tied to the value dimension of animal welfare and ethics. The fifth stakeholder-people-pertains to the human class, tied to the value dimension of human societies, comprising ethical, economic, cultural, recreational, aesthetic, etc., values. Given this variety in value dimensions, each of the general ethical principles has to be specified accordingly (Biasetti and de Mori 2021).

\subsection{Biotic entities (white-clawed crayfish, NICS, biodiversity)}

Concerning biotic entities, the three general ethical principles concur to shape a multi-dimensional concept of environmental value. The principle of well-being equates with conservation: maintaining stable and viable populations in the case of species, preserving richness and variety at all biological levels in the case of biodiversity.

Autonomy equates instead with respect for naturalness, understood as freedom from human intervention: hence letting the species, or the whole ecosystem, free to take its course.

Fairness equates with treating biodiversity and its components (biota, ecosystems, species, populations, processes, etc.) without bias grounded on human interests and preferences.

\subsection{Individual animals}

Concerning individual animals, the three general ethical principles concur to shape a multi-dimensional concept of animal welfare. Well-being equates, on the one hand, with health and functioning, and, on the other hand, with the absence of negative affective states and allowance of positive ones. As it will be discussed later, it is an open question if we can speak of "affective states" in decapod crustaceans. There is no doubt instead that we can assesswithin the limit of our present knowledge- their health and functioning.

Autonomy grasps a second aspect of animal welfare: respect for behavioral freedom according to species-specific 
Table 1 Starting draft for the EM

\begin{tabular}{|c|c|c|c|}
\hline & 1. Well-being & 2. Autonomy & 3. Fairness \\
\hline A. White Clawed Crayfish & A1. Conservation of the taxon & A2. Freedom from human intervention & A3. Respect for the worth of the taxon \\
\hline B. Crayfish NICS & B1. Conservation of the taxa & B2. Freedom from human intervention & B3. Respect for the worth of the taxa \\
\hline C. Biodiversity & $\begin{array}{l}\text { C1. Conservation of richness } \\
\text { and variety at all levels }\end{array}$ & C2. Freedom from human intervention & $\begin{array}{l}\text { C3. Respect for the worth of every } \\
\text { component }\end{array}$ \\
\hline D. Individual Crayfish & D1. Health and functioning & $\begin{array}{l}\text { D2. Freedom of expressing species- } \\
\text { specific behaviors }\end{array}$ & $\begin{array}{l}\text { D3. Respect for the worth of every } \\
\text { individual }\end{array}$ \\
\hline E. People & $\begin{array}{l}\text { E1. Economic, social, physi- } \\
\text { ological, and psychological } \\
\text { welfare }\end{array}$ & $\begin{array}{l}\text { E2. Freedom of choice. Capacity to exer- } \\
\text { cise the various fundamental aspects of } \\
\text { one's own persona. Self-determination }\end{array}$ & E3. Fair treatment \\
\hline
\end{tabular}

needs. Again, this has to be put in perspective. One of the main reasons why behavioral freedom should be considered valuable is due to its association with stress avoidance, and this, in turn, is mainly valuable as it may prevent negative affective states.

Finally, fairness equates here with unbiased treatment of the individual, meaning that, all things being equal, animals should be treated with dignity and respect, and that the welfare of one individual should not matter less than that of other individuals sharing similar characteristics.

\subsection{People}

Concerning people, well-being equates with the psychological and physiological welfare of individuals and the economic and social welfare of communities.

Respect for autonomy has to be understood as respect for freedom of choice and for self-determination of people, institutions, and communities involved. It is also the capacity to exercise the various fundamental aspects of one's own persona: one's profession, culture, traditions, etc.

Fairness instead equates with equal treatment of individuals, institutions, and communities, avoiding bias grounded on personal preferences or inclinations, partisanship, prejudices, and so on.

\subsection{The EM}

Table 1 contains the general draft of the EM. Starting from here, it is possible to sketch a more articulate framework of prima facie value-demands, as in Table 2. This EM contains various conflicts between the content of its cells are recapped in Table 3 .

\section{Analysis of the conflicts}

Conflicts highlighted by the EM (see Tables 2 and 3 ) can be subdivided in two groups.
The first group contains conflicts specifically related to the conservation of $A$. pallipes:

- Cell A1 vs cells A2, C1 and C2-conservation of ICS vs avoidance of conservation obstinacy.

- Cell A1 and A3 vs cells B2 and B3-conservation of ICS vs spreading of NICS.

- Cell A1 vs cells D1, D2, and D3-conservation of ICS vs safeguard of individual crayfish.

- Cell A1 and A3 vs cells E1, E2 and E3-conservation of ICS vs human interests.

The second group contains two conflicts related instead to the impact of NICS on biodiversity and human interests:

- Cells B2 and B3 vs cells C1, C2 and C3-spreading of NICS vs biodiversity protection.

- Cells B2 and B3 vs cells E1, E2, and E3-spreading of NICS vs human interests.

These latter pair of conflicts will be treated first, as their discussion introduces important elements to the discussion of the other four conflicts.

\subsection{Autonomy (B2) and fairness (B3) of NICS vs well-being (C1), autonomy (C2) and fairness (C3) of biodiversity}

Cell "B2" states a plain fact: that nature is not a fixed entity, and that colonization by "foreign" species-with the side-effects of the replacement of the "native" occupiers of the niche-is part and parcel of nature as much as predation, parasitism, and other seemingly callous natural phenomena. However, to this argument, it is possible to reply that no natural process is involved in the translocation of American and Australian species beyond strong distributional barriers like the oceans into Europe (against cell "C2"). Moreover, the current spreading of NICS at the expense of ICS is altering ecosystems in such a way to damage many other species, with a net biodiversity loss 
Table 2 Filled EM

\begin{tabular}{|c|c|c|c|}
\hline & 1. Well-Being & 2. Autonomy & 3. Fairness \\
\hline $\begin{array}{c}\text { A. White } \\
\text { clawed } \\
\text { crayfish }\end{array}$ & $\begin{array}{l}\text { A1. Conservation of the taxon: } \\
\text { A. pallipes is endangered, with a fragmented and } \\
\text { decreasing population. Its conservation depends } \\
\text { on human willingness to intervene } \\
\text { In particular, conservation could require careful } \\
\text { management of existing populations in order } \\
\text { to avoid further genetic impoverishment; } \\
\text { restricting interventions on rivers and streams } \\
\text { inhabited by the species, especially by reducing } \\
\text { or eliminating water depletion, modification of } \\
\text { riverbeds and banks, and spillage of wastewater; } \\
\text { providing means of connection between the } \\
\text { fragmented populations; focused re-introduc- } \\
\text { tions in appropriate sites; avoiding the spreading } \\
\text { of NICS (and outbreaks of } A \text {. astaci) by means } \\
\text { of population control and barriers; avoiding } \\
\text { accidental introduction of } A \text {. astaci in sites; con- } \\
\text { trol of introduced predators; contrast of poach- } \\
\text { ing; containment of competitors (by avoiding, } \\
\text { for instance, introduction of predator species); } \\
\text { periodical monitoring of the sites; promoting } \\
\text { conservation education }\end{array}$ & $\begin{array}{l}\text { A2. Freedom from human intervention: } \\
\text { Conservation obstinacy should be } \\
\text { avoided, meaning that some popula- } \\
\text { tions could be simply not possible } \\
\text { to conserve, and some sites could be } \\
\text { simply not possible to repopulate } \\
\text { Even when interventions are deemed } \\
\text { likely to succeed we still should exer- } \\
\text { cise caution, especially concerning re- } \\
\text { introductions and re-populations. For } \\
\text { instance, isolated populations could } \\
\text { have developed specific adaptations to } \\
\text { local conditions, and their gene-pool } \\
\text { could be modified by the introduction } \\
\text { of conspecifics from other popula- } \\
\text { tions }\end{array}$ & $\begin{array}{l}\text { A3. Respect for the worth of the taxon: } \\
\text { In the current context, } \text { A. pallipes } \\
\text { has little sustainable economic and } \\
\text { recreational value. Past claims that } \\
\text { it could be a good bioindicator of } \\
\text { water quality have been scaled down. } \\
\text { It has some limited potential as a } \\
\text { flagship and umbrella species, and it } \\
\text { can considered a heritage species. In } \\
\text { its native freshwater ecosystem, is a } \\
\text { keystone species } \\
\text { However, whatever the species' overall } \\
\text { appeal could be, we should still } \\
\text { consider it important to preserve for } \\
\text { its existence value }\end{array}$ \\
\hline $\begin{array}{l}\text { B. Cray- } \\
\text { fish } \\
\text { NICS }\end{array}$ & $\begin{array}{l}\text { B1. Conservation of taxa: } \\
\text { No NICS is presently at risk of extinction. Hence, } \\
\text { no actions are needed to preserve these species } \\
\text { in their native range } \\
\text { Outside their native range no conservation value } \\
\text { is attached to the presence of NICS }\end{array}$ & $\begin{array}{l}\text { B2. Freedom from human intervention: } \\
\text { Nature is not fixed and unchanging. } \\
\text { Species have always got ahead of } \\
\text { others, colonized new territories, and } \\
\text { replaced "natives". Every species } \\
\text { should have a certain freedom to } \\
\text { expand beyond its native range, even } \\
\text { if it comes at expense of other species } \\
\text { However, spreading of NICS out- } \\
\text { side their native areal cannot be } \\
\text { assimilated to the natural process of } \\
\text { interspecific competition, as it is arti- } \\
\text { ficially caused by human voluntary or } \\
\text { involuntary intervention }\end{array}$ & $\begin{array}{l}\text { B3. Respect for the worth of the taxa: } \\
\text { IAS replace indigenous species, cause } \\
\text { biodiversity loss, introduce new } \\
\text { diseases and zoonoses, and can pro- } \\
\text { voke economic damages. We should } \\
\text { nevertheless exercise some caution } \\
\text { in judging NICS, as not every non- } \\
\text { indigenous species can be automati- } \\
\text { cally classified an IAS } \\
\text { Moreover, NICS could have positive } \\
\text { qualities that could - at least in part } \\
\text { - soften our evaluation. They could } \\
\text { be, for instance, sources of economic } \\
\text { and recreational value } \\
\text { Finally, the same concept of "non- } \\
\text { indigenous" goes beyond its } \\
\text { scientific definitions, and can be also } \\
\text { tied to "being a recognized part of a } \\
\text { landscape". In this regard, it is worth } \\
\text { remembering that non-indigenous } \\
\text { species can quickly become a "rec- } \\
\text { ognized part of the landscape" of } \\
\text { laypeople. Such recognization may } \\
\text { not become evident until the species } \\
\text { is perceived to be threatened, and, } \\
\text { as such, can come as a surprise to } \\
\text { conservationists }\end{array}$ \\
\hline
\end{tabular}


Table 2 (continued)

\begin{tabular}{|c|c|c|c|}
\hline & 1. Well-Being & 2. Autonomy & 3. Fairness \\
\hline $\begin{array}{l}\text { C. Biodi- } \\
\text { versity }\end{array}$ & $\begin{array}{l}\text { C1. Conservation of richness and variety at all } \\
\text { levels: } \\
\text { Biodiversity should be preserved } \\
\text { Generally speaking, replacement of native species } \\
\text { with non-native species determines an overall } \\
\text { homogenization of biodiversity, and as such, it } \\
\text { should be avoided } \\
\text { Moreover, we should exercise an extra care for the } \\
\text { conservation of native keystone species, as their } \\
\text { disappearance or replacement could provoke a } \\
\text { further loss of biodiversity }\end{array}$ & $\begin{array}{l}\text { C2. Freedom from human intervention: } \\
\text { Conservation efforts should not com- } \\
\text { promise the naturalness of the areas } \\
\text { where they occur }\end{array}$ & $\begin{array}{l}\text { C3. Respect for the worth of every } \\
\text { component: } \\
\text { Respecting biodiversity means that we } \\
\text { should not privilege some parts of it } \\
\text { on the ground of our mere preferences } \\
\text { Some species, including NICS, may } \\
\text { be better suited to our economic } \\
\text { and recreational interests than other. } \\
\text { Nevertheless, we should consider the } \\
\text { effects they have on lesser charis- } \\
\text { matic or economically important } \\
\text { taxa, and the overall biodiversity } \\
\text { homogenization and impoverishment } \\
\text { they cause }\end{array}$ \\
\hline $\begin{array}{l}\text { D. Indi- } \\
\text { vidual } \\
\text { Cray- } \\
\text { fish }\end{array}$ & $\begin{array}{l}\text { D1. Health and functioning: } \\
\text { Having access to good living conditions depend- } \\
\text { ing on the circumstances (animals living in } \\
\text { the wild, in a lab, in fisheries, in an aquarium, } \\
\text { etc.). Having access, for instance, to good } \\
\text { quality water, suitable environments, avoiding } \\
\text { overcrowding, etc }\end{array}$ & $\begin{array}{l}\text { D2. Freedom of expressing species- } \\
\text { specific behaviors: } \\
\text { Having access to an environment suf- } \\
\text { ficiently not degraded (if in the wild) } \\
\text { or enough enriched (if kept captive) } \\
\text { to be capable to express the standard } \\
\text { behavioral repertoire }\end{array}$ & $\begin{array}{l}\text { D3. Respect for the worth of every } \\
\text { individual: } \\
\text { Crustaceans, like most invertebrates, } \\
\text { receive scarce empathy. This should } \\
\text { not prevent us to treat crayfish in a } \\
\text { humane way - when manipulating } \\
\text { them, and especially when killing } \\
\text { them }\end{array}$ \\
\hline E. People & $\begin{array}{l}\text { E1. Economic, social, physiological, and psycho- } \\
\text { logical welfare: } \\
\text { Sustainable development and economic growth of } \\
\text { communities } \\
\text { Living in a healthy (not polluted) and vibrant } \\
\text { environment }\end{array}$ & $\begin{array}{l}\text { E2. Freedom of choice. Capacity to } \\
\text { exercise the various fundamental } \\
\text { aspects of one's own persona. Self- } \\
\text { determination: } \\
\text { Having access to recreational activities } \\
\text { concerning nature and animals. These } \\
\text { may include activities quite differ- } \\
\text { ent such as hiking, fishing, wildlife } \\
\text { observation, etc } \\
\text { Having access to scientific activities } \\
\text { Having the possibility to exercise one's } \\
\text { own culture and traditions } \\
\text { Having a say in the management of } \\
\text { biodiversity and natural resources in } \\
\text { the area }\end{array}$ & $\begin{array}{l}\text { E3. Fair treatment: } \\
\text { Fair distribution of costs and benefits } \\
\text { of policies along spatial, temporal, } \\
\text { social and cultural differences. These } \\
\text { includes both costs and benefits rela- } \\
\text { tive to conservation of A. pallipes } \\
\text { and spreading of NICS }\end{array}$ \\
\hline
\end{tabular}

superior to the mere substitution of one local species with another with a larger areal (against cell "C1").

This latter point, however, should not be assumed uncritically. As stated in cell "B3", NICS, as for every other non-native species, should be thoroughly evaluated in their impact before being considered IAS. Nevertheless, no matter how charitable we strive to be in this sense, there is enough evidence to conclude that, in this case, the negative outcomes - in terms of biodiversity loss (cell "C1") and necessity of intervention (cell "C2") - largely overcome the eventual possible positive outcomes.

Freshwater ecosystems cover just the $0.8 \%$ of Earth's surface, yet hosts an incredible amount of biodiversityfor instance, according to some estimates, the $9.5 \%$ of all described animal species (Strayer and Dudgeon 2010). Several characteristics of crayfish species make them potential candidates for a keystone role in freshwater ecosystems. They are large and long-lived invertebrates. They make up a significant portion of benthic biomass. They occupy a crucial place in freshwater food webs-feeding on macroinvertebrates, fish and amphibian eggs and larvae, macrophytes, algae, and detritus, being preyed, at the same time, by insects, fishes, birds, and mammals (Hirvonen 1992; Maran and Henttonen 1995; Gherardi 2006). Given these circumstances, the addition of a crayfish species to a particular freshwater ecosystem will very probably cause significant ecological alterations_concerning pressure on macroinvertebrates, macrophytes, fishes and amphibians, habitat change, shelter availability, and food resources for certain mammals, avians and fishes. This does not prove per se that substitution of an ICS with a NICS would cause a major disturbance in an ecosystem. However, NICS, due 
to some of the same characteristics (fast growth, earlier sexual maturity, high prolificity) that make them capable to outclass native species, are also capable to reach larger densities (Gherardi 2007), raising in this way the level of pressure and modifications normally exercised by ICS.

Moreover, different behavior and level of opportunism are other reasons why the impact on native biodiversity of NICS could be stronger than those of A. pallipes. On this regard, there is very substantial evidence concerning $P$. clarkii. In particular, the predatory prowess and opportunism of $P$. clarkii in respect of A. pallipes are more marked (Gherardi et al. 2001; Renai and Gherardi 2004), as it is its capacity to alter habitats (Souty-Grosset et al. 2016), its behavioral flexibility (Gherardi 2006), its predatoravoiding capacity (Acquistapace et al. 2003) and its tolerance to different environmental conditions (it is capable of surviving extreme conditions, and has been found even in groundwaters-Mazza et al. 2014). All these, combined with a higher density, make $P$. clarkii a stronger ecosystem engineer than A. pallipes, and, what is more important, one which can cause a biodiversity loss were it to replace a ICS (Rodríguez et al. 2005; Souty-Grosset et al. 2016; Casale 2018).

Similarly, replacement of $A$. pallipes with $P$. leniusculus has been proved to cause adverse effects on biodiversity due to a difference in capacity and habits of predation, and in habitat modification (Guan and Wiles 1997; Edmonds et al. 2011; Reynolds 2011; Holdich et al. 2014)—characteristics paired even in this case with a higher biomass (Guan and Wiles 1996). F. limosus is capable as well of reaching a much higher density than A. pallipes (Gherardi 2007), however, direct comparison suggests that $F$. limosus could have a lesser ecological impact than $P$. clarkiii and P. leniusculus (Dunoyer et al. 2014).

Due to their higher density, NICS can affect the composition of an ecosystem also by providing new food sources for fishes, birds, and mammals. As noted in several studies (Gherardi 2006; Holdich and Black 2007; Reynolds 2011), presence of NICS correlates with higher numbers in certain species of vertebrates. While this may sometimes be perceived as positive, the eventual growth of vertebrate population due to the spreading of NICS cannot compensate their overall impact-that of $P$. clarkii in particular-on invertebrates, amphibians, and macrophytes (Gherardi 2006), not only for ecological reasons but also for fairness reasons, as for the content of cell "C 3 ". Moreover, the presence of large reservoir of prolific NICS may actually assist the settlement of other IAS. Some introduced avian species, like the sacred ibis (Threskiornis aethiopicus) are known to thrive thanks to the food supplies provided by NICS such as $P$. clarkii (Cucco et al 2021). The introduced and ecologically disruptive brown rat (Rattus norvegicus) too can prosper where $P$. clarkii is abundant (Amori and Battisti 2008).

\subsection{Autonomy (B2) and fairness (B3) of NICS vs well-being (E1), autonomy (E2) and fairness (E3) of people}

Spreading of NICS, as prima facie allowed by arguments contained in cell "B2" and "B3", impacts human interests. The assessment of this impact-both in terms of costs and benefits (cells "E1" and "E2"), and of their spatial, temporal, and social distribution (cell "E3")—-is a rather complex issue. A good starting point is to identify the main reasons behind human-caused introductions of NICS. These mainly follow three pathways.

The first pathway is aquaculture. The first NICS imported in Europe, F. limosus, was introduced in Germany to replenish the depleted native stocks after the outburst of crayfish plague (Hirsch et al. 2008; Pârvulescu et al. 2009; Hesselschwerdt et al. 2009). P. leniusculus (Johnsen and Taugbøl 2010) and P. clarkii (Gherardi 2006) were introduced for similar reasons-respectively in Sweden and in Spain —and aquaculture is also at the origin for the presence in Europe of C. destructor and C. quadricarnatus (Holdich et al. 2009a; Kouba et al. 2014).

Aquarium and pet trade is a second pathway for the introduction of NICS (Gherardi et al. 2011; Kouba et al. 2014; Mazza et al. 2015), first in semi-controlled environments, secondarily to the wild following accidentally or voluntarily release. In this regard, the most emblematic case is that of $P$. virginalis - the so-called Marmorkrebs-a species capable of reproducing via parthenogenesis (hence, the "virginalis" specific epithet). The first known individual was reported in a German aquarium (Scholtz et al. 2003; Lyko 2017), and the species has since spread to various areas of Europe, Japan, and Madagascar via the aquarium trade (Martin et al. 2010). With the capacity of starting colonization with just one individual, $P$. virginalis was soon found also in the wild, including in Italy (Nonnis Marzano et al. 2009).

Fishing is a third source for the introduction. Fishers may accidentally transport NICS in their nets and equipment from one water body to another (Banha and Anastácio 2015). Uses of crayfishes as baits can become the source of the introduction of a NICS in new areas (Holdich et al. 2014). The voluntary release of NICS in waterbodies is all but uncommon, as it is done to restock a depleted area, use a prolific species of crayfish as a source of food for fishes, for testing the quality of waters (Holdich and Black 2007; Holdich et al. 2009a), or even for "homemade" restoration attempt erroneously perpetrated by local people (Peay 2009; Bonelli et al. 2017).

Economic and recreational reasons seem then to explain much of the success of NICS in Europe. In this regard, some estimates are that $P$. leniusculus introduction in Sweden neutralized the economic damage caused by the decimation of the native population of $A$. astacus due to crayfish plague 
Table 3 Value conflicts in the EM

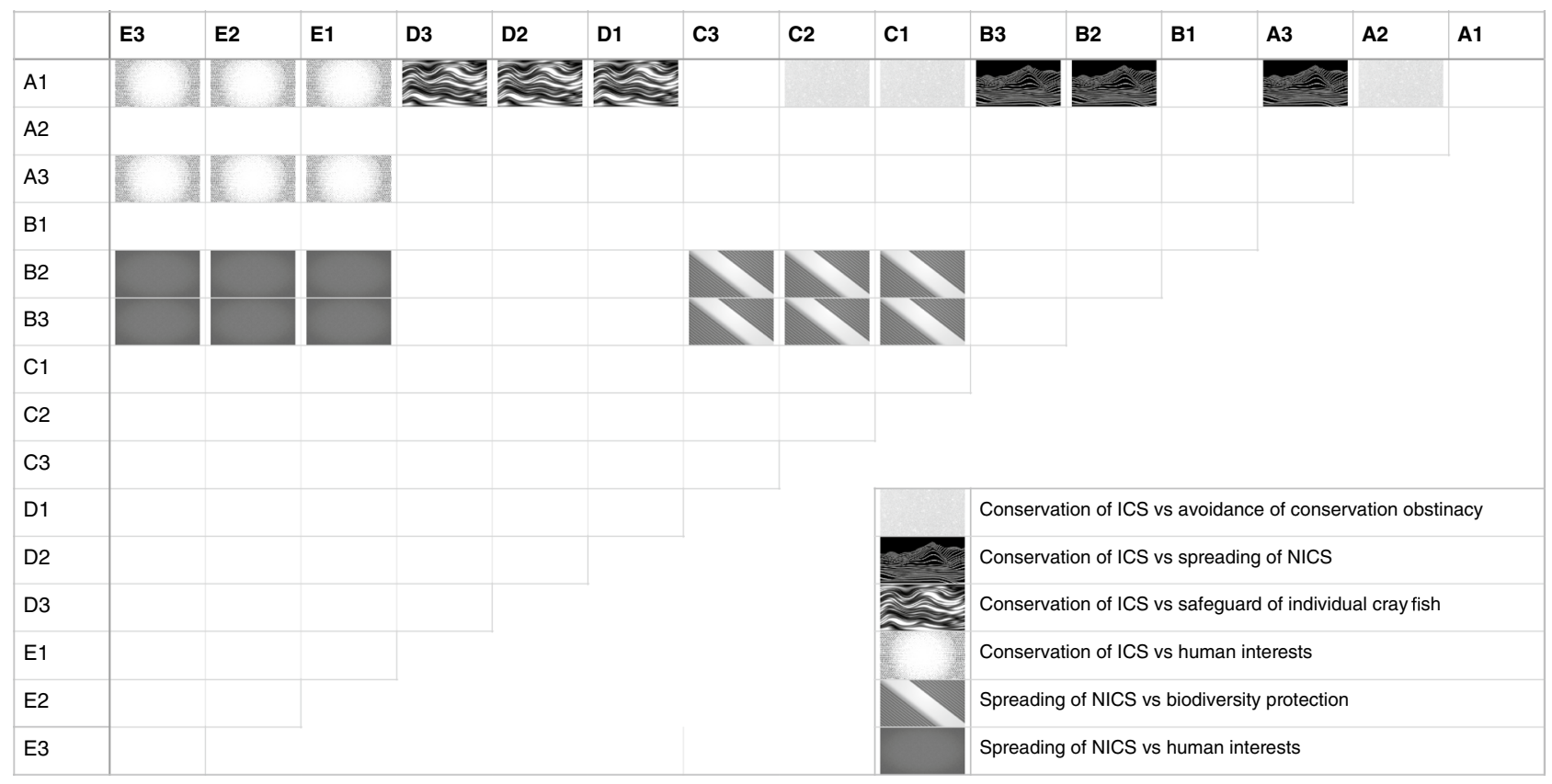

(Jernelöv 2017). Worldwide $P$. clarkii production nearly tripled in ten years between 2008 and 2017, while its market value quintupled (FAO 2019), at a time when Spain was the third world producer behind China and USA (Gaudé 2012).

However, this apparently positive economic figure has to be integrated with damages caused by NICS - especially $P$. clarkii, followed by $P$. leniusculus-which include erosion of banks and irrigation canals due to intense burrowing, invasion of sites dedicated to aquaculture, and damage to crops. For instance, in some years, $P$. clarkii may have damaged rice production in northern Italy as much as the 6\% (Souty-Grosset et al. 2016). Estimates done in France classifies both $P$. clarkii and $P$. leniusculus as pests, with annual costs quantified respectively in the order of $141 \mathrm{k}$ $€$ and $38 \mathrm{k} €$ per year (Wittmann and Flores-Ferrer 2015). Plans for sustainable aquaculture of $P$. clarkii in a controlled environment have been made (Conde and Domínguez 2015), but their economic viability is unclear.

Currently Art. 7 of EU Regulation no. 1143/2014 forbids cultivation and market-placement of $F$. limosus, $P$. leniusculus, and $P$. clarkii. In some European regions, like, for instance, Andalusia, catching and commercialization are still allowed as a way to control the NICS population (Consejería de Medio Ambiente y Ordenación del Territorio 2016). Small scale limitations of the general principle may be reasonable in a restricted territory, where complete eradication has no chance to succeed, a significant part of the population depend on the industry, and the NICS has culturally become a part of the local "recognized landscape"-especially if the alternative would be unchecked illegal catching and trafficking. However, while the absence of clear data, recurring fluctuation in the crayfish market, and complexities in the estimates of the impact on infrastructure and crops make hard to obtain a net balance, it should be clear that, in most cases, commercial exploitation of NICS exacts a high social cost, which is very likely covered only in part by taxation on generated profits. The economic value of NICS, in this sense, it is not distributed according to the criterion of fairness (cell "E3") — as benefits are limited to specific individuals, while costs fall on all society-and are very probably not sustainable, as required by cell "E1".

The same can be said about the recreational value of NICS related to fishing. Given their destabilizing effect on the ecosystem, it is far from clear if the presence of NICS could favor the presence of a larger population of fish, or if, on the contrary, it could diminish the numbers of species sought after by anglers.

NICS, with their higher biomass, can raise the numbers of some avian species (Barbaresi and Gherardi 2000; Rodríguez et al. 2005). This could be interpreted as a possible benefit for bird watchers and other eco-tourists. However, while some species surely profit from the presence of NICS, others see instead their numbers decrease (Rodríguez et al. 2005). Moreover, biodiversity homogenization paired with diminution of macrophytes and increased water turbulence (Rodríguez et al. 2005; Souty-Grosset et al. 2016; Casale 2018) may have an adverse effect on the aesthetic enjoyment and on the edutainment and transformative experiences associated with eco-tourism - as they are expressed in cell "E2".

As loss in biological diversity correlates with loss of cultural diversity (Pretty et al. 2009), the introduction of 
NICS - with their corollary of reduction of ICS, and all related local traditions-fails another aspect of the content of cell "E2". However, on this latter point, it must be noted that NICS can also acquire a "cultural" value of some sort. Human communities living in an area where a NICS is present may fail to recognize it as alien, because, for them, it has become part of the cultural landscape. In Sweden, for instance, where kräfrskivor-crayfish parties-are important social occurrences, public opinion has shown a certain concern about EU regulation on invasive species, as the presence of $P$. leniusculus is generally not seen as an issue (Jernelöv 2017). Similarly, in the low Guadalquivir area of Andalusia, P. clarkii-the cangrejo rojo-after less than a half-century from its introduction has become an important part of the gastronomic and cultural identity (Clavero 2016; Miles 2018; Rodríguez-Estival et al. 2019), as it is in some areas in Italy (Delmastro 2017).

This cultural component associated with the definition of indigenous and non-indigenous (cell "B3") should not be underestimated. The same A. pallipes reached Ireland only during the middle ages probably thanks to the taste of monks and their need for proteins during lent (Gherardi 2011), and, in all likelihood, in all the British Isles the white-clawed crayfish meets the official criteria for being considered an indigenous species - diffusion in the wild before $1500 \mathrm{AD}$ only for just for a handful of centuries (Holdich et al 2009b). However, from a cultural standpoint, there is no doubt that it is considered as much indigenous in the British Isles as it is in the rest of Europe, where its presence has a longer history.

In this latter sense, while it is rather dubious that the introduction of NICS in Europe have helped to satisfy the overall value-demands expressed in cells "E1", "E2", "E3", control of NICS should nevertheless always done following a contextualizing analysis, and by tailoring specific actions to the local reality.

\subsection{Well-being (A1) of the white-clawed crayfish vs autonomy of the white-clawed crayfish (A2), and well-being (C1) and autonomy of biodiversity (C1 and C2)}

Conservation obstinacy - something analogous to therapeutic obstinacy or futile medical care in human medicinemay be defined as the beginning or the prolonging of conservation efforts even when their specific object is irreversibly compromised - meaning that it cannot be restored or brought again to self-sustainability. The faults of conservation obstinacy should be clear. It leads to a waste of energy, time, funding, and other resources that could be better employed in other efforts (cell "Cl"). When it involves the manipulation of living beings, it may also result in an assault on their dignity as living — and perhaps even sentient—beings (cell "D3"). Finally, on a more abstract level, it violates nature's autonomy, by imposing a static frame as much anthropocentric as the harm done in the first place (cells "A2" and "C2").

Careful prior estimation of the probability of success of a conservation effort is the best way to avert conservation obstinacy. Besides social factors, the major critical aspects in possible conservation efforts for A. pallipes are control of NICS, and relocation or translocation attempts. Control of NICS, for instance, poses several potential issues. The most relevant is effectiveness, as complete eradication is in most cases not possible or not viable, and containment of the alien population may be difficult, costly, and hard to maintain (Gherardi 2006; Falaschi et al. 2020).

Control of introduced predators may pose other issues. This not only because of the objective difficulties of managing and controlling IAS, but also because of the difference in charisma between predator and prey. As demonstrated by the history of the attempted eradication of the grey squirrel ( $\mathrm{Sci}$ urus carolinensis) in Italy (Bertolino and Genovesi 2003), control of charismatic IAS may encounter social opposition. On this regard, there is little doubt that between $N$. vison and $P$. lotor on the one hand, and A. pallipes on the other, the freshwater invertebrate will be considered less charismatic than the two terrestrial mammals. Yet, arguments from charisma fail the requisite of fairness expressed in cell "C3", and as such, they are ethically unsound. Still, they can have a negative effect on the conservation management of charismatic IAS if the ground for their rebuttal is not carefully prepared beforehand (Jarić et al. 2020).

Reintroduction and relocation pose another set of problems. Usually, the first choice for reintroduction and relocation are sites where there is some sort of historical evidence of the past presence of the species. However, as it is stressed in guidelines (IUCN/SSC 2013), investigations to address the reasons why the species became extinct in these sites are an absolute prerequisite. This is especially the case of $A$. pallipes, because if the preexisting population was wiped by the crayfish plague, it may be that the site could be vulnerable to new outbreaks if the spreading source is not removed (Souty-Grosset et al. 2006).

Even mere proximity with sites where NICS are present can be an alarming sign. A. astaci moves along NICS, in the equipment or on the boot soles of anglers and fishermen, through fishes and birds. This means that sites free of $A$. astaci but near to other waterbodies where the oomycete is likely to be found - that is, where NICS live - can be nevertheless dangerous, even with no direct connections present (Manenti et al. 2019a).

Other species than NICS should also be taken in consideration. For instance, the native freshwater crab Potamon fluviatile is known to exercise dominance on A. pallipes, and the two species never occur in syntopy (Barbaresi and Gherardi 1997). Introduction of fishes known to prey on juveniles of A. pallipes-like the river trout Salmo trutta 
fario, very much appreciated by anglers - in sites chosen for reintroduction or relocation should be avoided. Moreover, due to the general capacity of habitat engineering of crayfish species, possible impact on existing biodiversity should also be evaluated when reintroduction or relocation are practiced in areas where previous colonization is uncertain.

Another variable to be considered-when captive breeding precedes reintroduction-is animal personality. Crayfish show individual variability along the shy/bold personality ax (Gherardi et al. 2012). Bold individuals studied in captivity show a higher reproductive success, shy individuals have instead a better survival rate. The natural distribution between shy and bold individuals is probably the result of an equilibrium between two different behavioral strategies. Yet, this equilibrium could be easily altered during a captive breeding program, as bold individuals, if unchecked, would be able to produce a larger number of offspring than shy individuals.

\subsection{Well-being (A1) and fairness (A3) of the white-clawed crayfish vs autonomy (B2) and fairness (B3) of NICS}

Spreading of NICS (cells "B2" and "B3") is one of the main causes for the demise of $A$. pallipes (against cells "A1" and "A3"). This happens because NICS exercise dominance on A. pallipes and may carry the crayfish plague. For the latter reasons, proximity and connection between sites hosting ICS and NICS should be avoided. The ecological requirements of A. pallipes seem to not completely overlap with those of NICS (Manenti et al. 2014)—usually leaving the higher parts of streams, nearer the spring, to the ICS-however, this differential distribution may be just provisional or due to artificial or natural barrier preventing the transit upstream of NICS. In fact, the creation of artificial barriers has been suggested as a measure for containing the spread of NICS and shielding existing populations of $A$. pallipes from possible non-crayfish carriers of $A$. astaci moving upstream (Krieg and Zenker 2020). However, this creates a potential conflict with other biodiversity conservation efforts (cell " $\mathrm{C} 1$ "), as stream connectivity is important for fish and invertebrate ecology (Manenti et al. 2019a). This potential conflict could be mitigated in two mutual ways. On the one hand, it could be addressed by adopting a pragmatic approach that does not exclude either of the two options a priori but evaluates case by case which one to prefer based on the local ecological context. On the other hand, it could be addressed by refining the construction techniques of barriers so that they allow the selective passage of fish, while preventing that of crayfish (Krieg et al. 2021).

Moreover, NICS — and especially P. clarkii (Gherardi and Barbaresi 2000)—possess a great dispersion capacity, which could make in time barriers insufficient. Human-caused translocation - intentional or not — could be another way for NICS to circumvent barriers (Bonelli et al. 2017). In the end, this means that populations of NICS living close to A. pallipes should be monitored and controlled-as there is little chance for success for the more extreme, but decisive, option of eradication. Several ways of controlling populations of NICS are discussed in the literature, including removal by trappings, drainage of waterbodies, introduction of predators (for instance the European eel, Anguilla anguilla), autocidal methods like the sterile male release technique (SMRT), and use of biocides (Aquiloni et al. 2010; Gherardi et al. 2011; Donato et al. 2018; Peay et al. 2019). All these systems, with the addition of artificial barriers, could be used to halt the expansion of NICS toward the last refuges of A. pallipes.

From a value standpoint, however, are these efforts worthwhile? Cell "A3" states that conservation of A. pallipes should be valuable whatever the usefulness of this species could be. This "existence" value, nevertheless, while surely important, cannot be considered in an absolute sense in a world of limited resources and competing interests. Other qualities of $A$. pallipes must be weighted to reach a satisfying answer to the previous question.

Concerning biodiversity conservation, such qualities could reside in the potential expressed by A. pallipes as a surrogate species. Its status as a possible bioindicator species is debated, but there is a general consensus concerning the limits of such an attribution (Füreder and Reynolds 2003; Scalici and Gibertini 2005; Nardi et al. 2005; Favaro et al. 2010; Gherardi 2011). However, albeit not in the standard meaning of a species requiring a large areal for its protection (Favreau et al. 2006), the white-clawed crayfish qualifies as an umbrella species (Füreder et al. 2003). Conservation efforts for $A$. pallipes such as protecting the mountain streams from excessive water abstraction, for instance, are a way to protect the whole freshwater ecosystem. In this sense, A. pallipes meets the definition of an umbrella species-one whose conservation permits the conservation of many other species. Moreover, A. pallipes is an important keystone species, and its extinction can have several significant negative effects on the biodiversity of its native range, especially on small streams and creeks.

Given these latter arguments, the conflict between the spreading of NICS and the conservation of A. pallipes is not a simple matter of preference between different species but is a crucial part of the larger conflict between spreading of NICS and biodiversity conservation. No NICS is presently vulnerable or endangered (Adams et al. 2010; Crandall 2010; Schuster et al. 2010), and, as IAS, their impact on biodiversity is negative outside their native areal. Conservation of A. pallipes, instead, is clearly valuable both for the existing value of the species and for its role as an umbrella and keystone species. 


\subsection{Well-being (A1) of the white-clawed crayfish vs well-being (D1), autonomy (D2) and fairness (D3 of individual crayfish (whatever their species)}

Conservation efforts (cell "A1") very often intersect animal welfare issues (cells "D1", "D2", and "D3"), yet, these latter not always receive the attention they deserve. This happens also with reintroduction (Harrington et al. 2013), and IAS control (Littin and Mellor 2005). Reintroduction, for instance, entails capture and assessment of living specimen, captive breeding (eventually), transportation, release, and monitoring. All these activities involve the manipulation of animals and may lead to harm or even death. IAS control, on the other hand, can be even more invasive, as it entails capture and usually killing of a great mass of individuals, or, in the case of SMRT methodology, capture followed by neutering, release, and monitoring.

Animal welfare may have many meanings and pursue different goals (Fraser 2008): in a first sense, it could be equated with physical health and functioning; in a second, with minimization of unpleasant affective states like fear and pain, and with the allowance of normal pleasures; in a third with development and use of natural adaptations and capabilities. Concerning the frame of the EM, the first and the second meanings fall under the general principle of wellbeing (cell "D1"), while the third falls under autonomy (cell "D2").

Since we are discussing of invertebrates, inclusion in the EM of the second meaning may be considered inappropriate. In fact, pain and related attribution of affective states in crustaceans is a relatively new field of research and debate. By large, it is a controversial field, with some promising evidence, yet still much to be accomplished (Gherardi 2009). Studies have mainly focused on decapods such as the shrimp Squilla mantis (Maldonado and Miralto 1982), the prawn Palaemon elegans (Barr et al. 2008), the hermit crab Pagurus bernhardus (Elwood and Appel 2009; Appel and Elwood 2009a, b; Magee and Elwood 2016), the crab Carcinus maenas (Kotsyuba et al. 2010; Barr and Elwood 2011; Magee and Elwood 2013; Elwood and Adams 2015; Elwood et al. 2017), and two species of crayfishes, A. astacus (Hendrycks et al. 2014) and P. clarkii (Kawai et al. 2004; Puri and Faulkes 2010, 2015; Fossat et al. 2014; Adams et al. 2019).

The results of these studies do not support any definitive conclusions for or against the presence of unpleasant affective states in decapods. Nociception (which is not pain, but, realistically, its prerequisite) has been proven in some cases (Puri and Faulkes 2015-concerning P. clarkii), yet other indirect evidence of nociceptive response gathered by electroshock or exposition to extreme $\mathrm{pH}$ has been contested from a methodological standpoint (Diggles 2019) or has not been replicated (Puri and Faulkes 2010, concerning
Barr et al. 2008). On the other hand, sensibility to analgesia, avoidance learning, and trade-offs between stimulus avoidance have been all observed (Elwood 2011), as well as personality (Gherardi et al. 2012).

There is then some potential for attributing to (certain) crustaceans affective states of some sort, but, at the present state of research, no specific conclusion can probably be reached-and surely no general conclusion, given the restricted number of species used. What is however probable is that, if pain and other similar states can be experienced by crustaceans, they cannot be expected to follow the same logic and rules that we know in vertebrates. As shown for instance by Puri and Faulkes (2015), P. clarkii holds nociceptive circuits for heat, but not for cold, meaning that exposition to very low-and damaging - temperature could be not associated with eventual negative affective states.

It is then probably reasonable in the present case to not consider the second meaning of animal welfare as a justified application of the principle of individual animal wellbeing. However, this does not exclude the first and the third meanings as legitimate value-demands to be included in the EM (cell "D1" and "D2"). Specific applications of these could be, for individual crayfish, having access to good living conditions-such as good quality water, suitable and enriched environment, not overcrowded, etc.- depending on its present state-in the wild, laboratory, aquarium, etc. Conservation projects that require the manipulation of living crayfish for any reason (monitoring, experiments and research, captive breeding, etc.) should strive to satisfy these minimal demands. Moreover, even if we do not have conclusive evidence concerning the existence of pain and suffering in crayfishes, conscious use of the precaution principle suggests to exercise some humane considerations when there is the need of manipulating and-especially—killing them, given the respect for the worth of every individual being we should have, even if it, as an invertebrate, is prone to receive scarce empathy from our part (cell "D3").

\subsection{Well-being (A1) of the white-clawed crayfish vs well-being (E1), autonomy (E2) and fairness (E3) of people}

Social factors are crucial in determining the success of conservation efforts (Giakoumi et al. 2018; Catalano et al. 2019). Approval and support from local communities are fundamental requisites for conservation projects that may involve actions like monitoring, habitat protection, reintroduction and relocation, control of IAS, and so on. In this specific case, action on behalf of the conservation of $A$. pallipes (cell "A1") may intersect with the interests of many different categories of people (cells "E1", "E2", and "E3"). Possible clashes, then, must be carefully considered and evaluated. 
Fishers represent the first category of people affected. They should be instructed, for instance, to avoid risky behaviors, such as not cleaning nets and equipment when moving from a waterbody to another. Moreover, the introduction of competitor fish species in an area where A. pallipes is being restocked should be discouraged, and strict control on poaching and on the introduction of NICS to new sites should be enforced. Literature shows that pro-environmental attitude can be successfully passed to anglers through specific educational programs (Fujitani et al. 2016; Mannheim et al. 2018). Similar interventions could also be needed to align anglers with the general goals of conserving ICS. It should be noted, however, that some of the behaviors to be encouraged in anglers could be burdensome for them, especially those concerning the precautions to be taken in order to avoid spreading of $A$. astaci.

Conservation of $A$. pallipes is clearly at odds with the interests of people involved in the aquarium and pet trade of crayfish. Some of the most sought-after pet crayfish-due to their beauty, novelty, and peculiarity-are NICS (Chucholl and Wendler 2017). In these cases, however, there are few if any reasons for not limiting the trade. While uncommon, behaviors like keeping crayfish in outdoor ponds, or releasing surplus in natural habitats, are present (Patoka et al. 2014), and are behind many cases of introduction of NICS. Since the economic and recreational benefits of aquarium and pet trade of crayfish are limited to a relatively small group of people, while the costs are instead socially shared, considerations of fairness (cell "E3") would push for a limitation of these activities. However, regulations seem to have a limited effect in this case (Faulkes 2015). On the one hand, laws on the subject are often poorly communicated and enforced (Patoka et al. 2018). On the other hand, online trade and exchange are objectively difficult to control (Faulkes 2018). Moreover, literature reports that fishkeepers are, on average, less aware of the impact of IAS than anglers (Banha et al. 2019). Hence, it is probable that, in order to ameliorate the overall situation, different interventions have to be taken into account-better communication and enforcement of laws, a "white list" approach on crayfish trade regulation, environmental education programs targeted at fishkeepers, and encouragement of humane euthanasia of unwanted pets (Patoka et al. 2018).

Other possible conflicts appear if we turn to society at large. A great deal of interventions needed to preserve or restore habitat for A. pallipes, for instance, while could provide long-term benefits, could clash with more immediateand often short-sighted-social and economic interests. Urban expansion is a self-evident case. Water abstraction for intensive agriculture is another. In time, unregulated urban development and over-exploitation of water resources could cause severe social costs and prove themselves unsustainable even for an adaptable species like humans (Rosenblatt
2005). At the present, however, there are many difficulties in defending the conservation of small invertebrates like $A$. pallipes (Cardoso et al. 2011).

What appears to be a significant issue, in this case, is the lack of immediate relevance for most people of the species. A. pallipes does not possess the standard characteristics of charismatic species (Ducarme et al. 2013) - as a matter of fact, few invertebrates have them. Empathy for crustaceans-and, again, for invertebrates in general-is usually low, meaning that few people will be inclined to care for the species without further decisive reasons. Moreover, A. pallipes has little economic and recreational value.

There is, however, some consensus concerning the potentiality of A. pallipes as a flagship species (Füreder and Reynolds 2003), indicating that its conservation efforts are likely to receive nevertheless some degree of support from the public. This is probably because, in the context of local freshwater ecosystems, A. pallipes can still be considered as more charismatic than the majority of the rest of the fauna. Moreover, as crayfish are traditionally appreciated by people for their indirect and direct uses (Gherardi 2011), A. pallipes enjoys an important heritage value and can be considered a heritage species (Füreder and Reynolds 2003). It is, in this sense, a part of the common, recognized landscape, and, as such, as something that is perceived by some people as worth to be protected.

\section{Conclusion}

Conservation of A. pallipes is inlaid in a complex framework of different values, raising several potential conflicts. Generally speaking, this kind of conflicts rarely has a "solution" like those possessed by mathematical or logical problemssomething already there and waiting to be discovered. "Solutions" to conflicts between values have instead to be reached through a balancing of the different demands involved-balancing which has, in turn, to be grounded on evidence and facts. In this specific case, some of the conflicts appear to not have a clear solution. This is especially true for the latest conflict, where the conservation efforts for A. pallipes are measured against interests which, while surely partial and short-sighted, tend nevertheless to be strong, or, in any case, difficult to contrast.

The EM proposed here provides however with some arguments to avoid this unsatisfying result. From an ethical standpoint, the three value demands that seem to have a greater specific weight all support arguments that can help mitigate the various conflicts in favor of $A$. pallipes conservation.

The first value demand arises from the principle of fairness. Many of the potential conflicts described in the EM 
fade away when we adopt an impartial point of view on biodiversity - that is, a point of view where all potential biases tied to our preferences are set aside. This is particularly effectual when conservation efforts for A. pallipes clash with the widespread preference for more charismatic vertebrates: for instance, when invasive carnivore control is needed, or when control of NICS can lead to the impoverishment of the number of certain vertebrates.

The second value demand arises again from the principle of fairness, this time concerning people. Beyond its overall net balance, the economy of NICS must be also assessed concerning the social distribution of costs and benefits. In many cases, these are not distributed fairly, with benefits restricted to few people, and costs socially distributed. A similar argument can also be made concerning the recreational value associated with NICS.

The third value demand is relative to biodiversity conservation. As said, crayfish species have several features of keystone species. In this sense, ICS are responsible for shaping their environment in an original and unique way. Removal on ICS causes a loss of this uniqueness, which may be further harmed by the homogenization effect created by NICS. The potential loss of biodiversity caused by the disappearance of a keystone ICS should then be considered as the main reason for avoiding the decline and possible extinction of $A$. pallipes. This, in turn, requires that people would be capable to positively value biodiversity per se.

There could be many reasons for valuing biodiversity (Biasetti \& de Mori 2016), including social and economic values. However, the social and economic benefits of conserving biodiversity can be hard to visualize, and as much as slow to materialize, with years needed before they outweigh their required costs-while politics, economics, and people's day-to-day decisions operate within a shorter time horizon, and on the basis of options before everyone's eyes. This, again, highlights the need for conservation education. Only by addressing the social concerns and providing an articulate frame of reasons conservation programs may succeed and be sustainable in the long period. The involvement of communities and stakeholders need informed consent: and this can be reached only by providing people not just with transparent communication on the project-including the spatial and temporal distribution of its costs and benefits-but also with the appropriate ecological framework to process the given information. Even conservation actions for disregarded invertebrate species like worms are possible if adequate educational activities are provided to people (Manenti et al. 2019b).

On the other hand, conservationists should be capable of recognizing and move between the complex web of values that stands behind their efforts. There are indeed many situations where conservation efforts are not naturally aligned with social, economic, and animal welfare demands. Compromises must hence be continuously reached, and careful scrutiny and analysis of the values involved need to be performed. The EM is, in this sense, an ethical reasoning tool that can be employed in order to give voice to all the different stakeholders involved-including those who do not have a real voice-in this way reminding us that the human immediate interests are not always the only one involved.

Acknowledgements We are grateful to Elena Eustacchio (University of Milan, Department of Biosciences) for the graphical abstract artwork. We would also like to thank Simone Grigoletto and two anonymous referees of Rendiconti Lincei for the valuable suggestions received regarding the manuscript.

Funding Open Access funding enabled and organized by Projekt DEAL.

Open Access This article is licensed under a Creative Commons Attribution 4.0 International License, which permits use, sharing, adaptation, distribution and reproduction in any medium or format, as long as you give appropriate credit to the original author(s) and the source, provide a link to the Creative Commons licence, and indicate if changes were made. The images or other third party material in this article are included in the article's Creative Commons licence, unless indicated otherwise in a credit line to the material. If material is not included in the article's Creative Commons licence and your intended use is not permitted by statutory regulation or exceeds the permitted use, you will need to obtain permission directly from the copyright holder. To view a copy of this licence, visit http://creativecommons.org/licenses/by/4.0/.

\section{References}

Acquistapace P, Hazlett BA, Gherardi F (2003) Unsuccessful predation and learning of predator cues by crayfish. J Crustacean Biol 23:364-370. https://doi.org/10.1163/20021975-99990346

Adams S, Schuster GA, Taylor CA (2010) Orconectes limosus, Spinycheek Crayfish. In: IUCN Red List Threat Species 2010 e.T153764A4541724. https://doi.org/10.2305/IUCN.UK.2010-3. RLTS.T153764A4541724.en

Adams R, Stanley CE, Piana E, Cooper RL (2019) Physiological and behavioral indicators to measure crustacean welfare. Animals. https://doi.org/10.3390/ani9110914

Alderman DJ (1996) Geographical spread of bacterial and fungal diseases of crustaceans. OIE Rev Sci Tech 15:603-632. https://doi. org/10.20506/rst.15.2.943

Amori G, Battisti C (2008) An invaded wet ecosystem in Central Italy: an arrangement and evidence for an alien food chain. Rend Fis Acc Lincei 19:161-171. https://doi.org/10.1007/ s12210-008-0009-5

Appel M, Elwood RW (2009a) Motivational trade-offs and potential pain experience in hermit crabs. App An Behav Sci 119:120 124. https://doi.org/10.1016/j.applanim.2009.03.013

Appel M, Elwood RW (2009b) Gender differences, responsiveness and memory of a potentially painful event in hermit crabs. An Behav 78:1373-1379. https://doi.org/10.1016/j.anbehav.2009.09.008

Aquiloni L, Tricarico E, Gherardi F (2010) Crayfish in Italy: distribution, threats and management. Int Aquat Res 2:1-14

Banha F, Anastácio PM (2015) Live bait capture and crayfish trapping as potential vectors for freshwater invasive fauna. Limnologica 51:63-69. https://doi.org/10.1016/j.limno.2014.12.006 
Banha F, Diniz A, Anastácio PM (2019) Patterns and drivers of aquarium pet discharge in the wild. Ecol Indic 106:105513. https://doi. org/10.1016/j.ecolind.2019.105513

Barbaresi S, Gherardi F (1997) Italian freshwater decapods: Exclusion between the crayfish Austropotamobius pallipes (Faxon) and the crab Potamon fluviatile (Herbst). Bull Fr la Pech la Prot des Milieux Aquat 70:731-747. https://doi.org/10.1051/kmae/ 1997047

Barbaresi S, Gherardi F (2000) The invasion of the alien crayfish Procambarus clarkii in Europe, with particular reference to Italy. Biol Invasions 2:259-264. https://doi.org/10.1023/A:10100 09701606

Barr S, Elwood RW (2011) No evidence of morphine analgesia to noxious shock in the shore crab, Carcinus maenas. Behav Processes 86:340-344. https://doi.org/10.1016/j.beproc.2011.02.002

Barr S, Laming PR, Dick JTA, Elwood RW (2008) Nociception or pain in a decapod crustacean? An Behav 75:745-751. https://doi.org/ 10.1016/j.anbehav.2007.07.004

Benvenuto C, Gherardi F, Ilhéu M (2008) Microhabitat use by the white-clawed crayfish in a Tuscan stream. J Nat Hist 42:21-33. https://doi.org/10.1080/00222930701799090

Bertolino S, Genovesi P (2003) Spread and attempted eradication of the grey squirrel (Sciurus carolinensis) in Italy, and consequences for the red squirrel (Sciurus vulgaris) in Eurasia. Biol Conserv 109:351-358. https://doi.org/10.1016/S0006-3207(02)00161-1

Biasetti P, de Mori B (2016) A framework of values: reasons for conserving biodiversity and natural environments. Etica Polit 18:527-545

Biasetti P, de Mori B (2019) Le matrici etiche nella conservazione della biodiversità. Etica Polit 21:233-254. https://doi.org/10.13137/ $1825-5167 / 26629$

Biasetti P, de Mori B (2021) The ethical matrix as a tool for decisionmaking process in conservation. Front Environ Sci 9:584636. https://doi.org/10.3389/fenvs.2021.584636

Biasetti P, Florio D, Gili C, de Mori B (2020) The ethical assessment of touch pools in aquariums by means of the ethical matrix. $\mathrm{J}$ Agric Environ Ethics 33:337-353. https://doi.org/10.1007/ s10806-020-09823-2

Boncompagni L, Molfini M, Ciampelli P, Fazzi P, Lucchesi M, Mori E, Petralia L, Mazza G (2021) No country for native crayfish: importance of crustaceans in the diet of native and alien Northern raccoons. Ethol Ecol Evol. https://doi.org/10.1080/03949370. 2021.1872710

Bonelli M, Manenti R, Scaccini D (2017) Mountain protected areas as refuges for threatened freshwater species: the detrimental effect of the direct introduction of alien species. Eco Mont 9:23-29. https://doi.org/10.1553/eco.mont-9-2s23

Boscherini A, Mazza G, Menchetti M et al (2019) Time is running out! Rapid range expansion of the invasive northern raccoon in central Italy. Mammalia. https://doi.org/10.1515/mammalia-2018-0151

Brusconi S, Bertocchi S, Renai B, Scalici M, Souty-Grosset C, Gherardi F (2008) Conserving indigenous crayfish: stock assessment and habitat requirements in the threatened Austropotamobius italicus. Aquat Conserv 18:1227-1239. https://doi.org/10. 1002/acq.935

Caprioli R, Cargini D, Marcacci M et al (2013) Self-limiting outbreak of crayfish plague in an Austropotamobius pallipes population of a river basin in the Abruzzi region (central Italy). Dis Aquat Organ 103:149-156. https://doi.org/10.3354/dao02571

Cardoso P, Erwin TL, Borges PA, New TR (2011) The seven impediments in invertebrate conservation and how to overcome them. Biol Cons 144(11):2647-2655. https://doi.org/10.1016/j.biocon. 2011.07.024
Casale A (2018) Estinzioni locali o globali. L'estinzione in entomologia: mito o realtà? Introduzione a una tavola rotonda. Atti Accad Nazionale Ital Entomol Anno LXVI 2018:143-148

Catalano AS, Lyons-White J, Mills MM, Knight AT (2019) Learning from published project failures in conservation. Biol Conserv 238:108223. https://doi.org/10.1016/j.biocon.2019.108223

Chucholl C, Wendler F (2017) Positive selection of beautiful invaders: long-term persistence and bio-invasion risk of freshwater crayfish in the pet trade. Biol Invasions 19:197-208. https://doi.org/10. 1007/s10530-016-1272-5

Clavero M (2016) Species substitutions driven by anthropogenic positive feedbacks: Spanish crayfish species as a case study. Biol Cons 193:80-85. https://doi.org/10.1016/j.biocon.2015.11.017

Conde A, Domínguez J (2015) A proposal for the feasible exploitation of the red swamp crayfish Procambarus clarkii in introduced regions. Conserv Lett 8:440-448. https://doi.org/10.1111/conl. 12164

Consejería de Medio Ambiente y Ordenación del Territorio (2016) Orden de 3 de agosto de 2016, por la que se aprueba el Plan de Control del Cangrejo Rojo (Procambarus clarkii) en las Marismas del Guadalquivir. Boletín Oficial Junta Andalucía $152: 81-110$

Cornalia E (1860) Sulla malattia dei gamberi. Atti della Soc Ital delle Sci Naturali 2:334-336

Crandall KA (2010) Procambarus clarkii, Red Swamp Crayfish. In: IUCN Red List Threat Species 2010 e.T153877A4557336. https://doi.org/10.2305/IUCN.UK.2010-3.RLTS.T153877A45 57336.en

Cucco M, Alessandria G, Bissacco M et al (2021) The spreading of the invasive sacred ibis in Italy. Sci Rep 11:1-13. https://doi.org/10. 1038/s41598-020-79137-w

Delmastro G (2017) Il gambero della Louisiana Procambarus clarkii (Girard, 1852) in Piemonte: nuove osservazioni su distribuzione, biologia, impatto e utilizzo (Crustacea: Decapoda: Cambaridae). Riv Piemont di Stor Nat 38:61-129

Diggles BK (2019) Review of some scientific issues related to crustacean welfare. ICES J Mar Sci 76:66-81. https://doi.org/10.1093/ icesjms/fsy058

Donato R, Rollandin M, Favaro L, Ferrarese A, Pessani D, Ghia D (2018) Habitat use and population structure of the invasive red swamp crayfish Procambarus clarkii (Girard, 1852) in a protected area in Northern Italy. Knowl Manag Aquat Ecosyst. https://doi.org/10.1051/kmae/2018002

Ducarme F, Luque GM, Courchamp F (2013) What are "charismatic species" for conservation biologists? Biosci Master Rev 1:1-8

Dunoyer L, Dijoux L, Bollache L, Lagrue C (2014) Effects of crayfish on leaf litter breakdown and shredder prey: are native and introduced species functionally redundant? Biol Invasions 16:15451555. https://doi.org/10.1007/s10530-013-0590-0

Edmonds NJ, Riley WD, Maxwell DL (2011) Predation by Pacifastacus leniusculus on the intra-gravel embryos and emerging fry of Salmo salar. Fish Manag Ecol 18:521-524. https://doi.org/10. 1111/j.1365-2400.2011.00797.x

Edsman L, Füreder L, Gherardi F, Souty-Grosset C (2010) Astacus astacus, Noble crayfish. In: IUCN Red List Threat SpeciesTM e.T2191A9338388. https://doi.org/10.2305/IUCN.UK.2010-3. RLTS.T2191A9338388.en

Elwood RW (2011) Pain and suffering in invertebrates? ILAR J 52:175-184. https://doi.org/10.1093/ilar.52.2.175

Elwood RW, Adams L (2015) Electric shock causes physiological stress responses in shore crabs, consistent with prediction of pain. Biol Lett 11:20150800. https://doi.org/10.1098/rsbl.2015.0800

Elwood RW, Appel M (2009) Pain experience in hermit crabs? An Behav 77:1243-1246. https://doi.org/10.1016/j.anbehav.2009. 01.028 
Elwood RW, Dalton N, Riddell G (2017) Aversive responses by shore crabs to acetic acid but not to capsaicin. Behav Process 140:1-5. https://doi.org/10.1016/j.beproc.2017.03.022

Falaschi M, Melotto A, Manenti R, Ficetola F (2020) Invasive species and amphibian conservation. Herpetologica 76:216-227. https:// doi.org/10.1655/0018-0831-76.2.216

FAO (2019) FAO yearbook. In: Fishery and aquaculture statistics 2017. Rome

Faulkes $\mathrm{Z}$ (2015) The global trade in crayfish as pets. Crustac Res 44:75-92. https://doi.org/10.18353/crustacea.44.0_75

Faulkes Z (2018) Prohibiting pet crayfish does not consistently reduce their availability online. Nauplius 26:1-11. https://doi.org/10. $1590 / 2358-2936 \mathrm{e} 2018023$

Favaro L, Tirelli T, Pessani D (2010) The role of water chemistry in the distribution of Austropotamobius pallipes (Crustacea Decapoda Astacidae) in Piedmont (Italy). Comptes Rend Biol 333:68-75. https://doi.org/10.1016/j.crvi.2009.09.017

Favreau JM, Drew CA, Hess GR et al (2006) Recommendations for assessing the effectiveness of surrogate species approaches. Biodivers Conserv 15:3949-3969. https://doi.org/10.1007/ s10531-005-2631-1

Fischer D, Pavlučík P, Sedláček F, Šálek M (2009) Predation of the alien American mink, Mustela vison on native crayfish in middle-sized streams in central and western Bohemia. Folia Zool 58:45-56

Fossat P, Bacqué-Cazenave J, De Deurwaerdère P et al (2014) Anxietylike behavior in crayfish is controlled by serotonin. Science (80) 344:1293-1297. https://doi.org/10.1126/science.1248811

Fraser D (2008) Understanding animal welfare. Wiley-Blackwell, Oxford

Fujitani ML, McFall A, Randler C, Arlinghaus R (2016) Efficacy of lecture-based environmental education for biodiversity conservation: a robust controlled field experiment with recreational anglers engaged in self-organized fish stocking. J Appl Ecol 53:25-33. https://doi.org/10.1111/1365-2664.12560

Füreder L, Reynolds JD (2003) Is Austropotamobius pallipes a good bioindicator? Bull Fr la Pech la Prot des Milieux Aquat. https:// doi.org/10.1051/kmae:2003011

Füreder L, Oberkofler B, Hanel R, Machino Y (2002) Freshwater crayfish in South Tyrol (Italy): distribution and protection measures of endangered Austropotamobius pallipes. Bull Fr la Pech la Prot des Milieux Aquat. https://doi.org/10.1051/kmae:2002056

Füreder L, Oberkofler B, Hanel R et al (2003) The freshwater crayfish Austropotamobius pallipes in South Tyrol: heritage species and bioindicator. Bull Fr la Pech la Prot des Milieux Aquat. https:// doi.org/10.1051/kmae:2003005

Füreder L, Gherardi F, Souty-Grosset C (2010a) Austropotamobius torrentium (errata version published in 2017). In: IUCN Red List Threat Species 2010, pp e.T2431A121724677

Füreder L, Gherardi F, Holdich D et al (2010b) Austropotamobius pallipes, white-clawed crayfish. In: IUCN Red List Threat Species 2017 e.T2430A9438817. https://doi.org/10.2305/IUCN.UK. 2010-3.RLTS.T2430A9438817.en

Gaudé AP (2012) Economic fishery from Procambarus introductions into Spain. World Aquac Soc 2012:52-55

Gherardi F (2006) Crayfish invading Europe: the case study of Procambarus clarkii. Mar Freshw Behav Physiol 39:175-191. https://doi.org/10.1080/10236240600869702

Gherardi F (2007) Understanding the impact of invasive crayfish. In: Biological invaders in inland waters: profiles, distribution, and threats. Springer, Dordrecht, pp 507-542

Gherardi F (2009) Behavioural indicators of pain in crustacean decapods. Ann Ist Super Sanita 45:432-438. https://doi.org/10.1590/ S0021-25712009000400013
Gherardi F (2011) Towards a sustainable human use of freshwater crayfish (Crustacea, Decapoda, Astacidea). Knowl Manag Aquat Ecosyst. https://doi.org/10.1051/kmae/2011038

Gherardi F, Barbaresi S (2000) Invasive crayfish: activity patterns of Procambarus clarkii in the rice fields of the lower Guadalquivir (Spain). Arch Hydrobiol 150:153-168

Gherardi F, Souty-Grosset C (2017a) Pontastacus leptodactylus, Slender-clawed Crayfish. IUCN Red List Threat Species 2017 e.T153745A120103207. https://doi.org/10.2305/IUCN.UK 2017-3.RLTS.T153745A120103207.en

Gherardi F, Souty-Grosset C (2017b) Pontastacus pachypus, thick-clawed crayfish. IUCN Red List Threat Species 2017 e.T153702A120106844. https://doi.org/10.2305/IUCN.UK 2017-3.RLTS.T153702A120106844.en

Gherardi F, Renai B, Corti C (2001) Crayfish predation on tadpoles: a comparison between a native (Austropotamobius pallipes) and an alien species (Procambarus clarkii). Bull Fr la Pech la Prot des Milieux Aquat. https://doi.org/10.1051/kmae:2001011

Gherardi F, Acquistapace P, Santini G (2004) Food selection in omnivores: a case study of the crayfish Austropotamobius pallipes. Archiv Hydrobiol 159:357-376. https://doi.org/10.1127/00039136/0159-0357

Gherardi F, Aquiloni L, Diéguez-Uribeondo J, Tricarico E (2011) Managing invasive crayfish: is there a hope? Aquat Sci 73:185-200. https://doi.org/10.1007/s00027-011-0181-z

Gherardi F, Aquiloni L, Tricarico E (2012) Behavioral plasticity, behavioral syndromes and animal personality in crustacean decapods: an imperfect map is better than no map. Curr Zool 58:567-579. https://doi.org/10.1093/czoolo/58.4.567

Giakoumi S, McGowan J, Mills M et al (2018) Revisiting "success" and "failure" of marine protected areas: a conservation scientist perspective. Front Mar Sci 5:1-5. https://doi.org/10.3389/fmars. 2018.00223

Guan R, Wiles PR (1996) Growth, density and biomass of crayfish, Pacifastacus leniusculus, in a British lowland river. Aquat Living Resour 9:265-272. https://doi.org/10.1051/alr:1996030

Guan RZ, Wiles PR (1997) Ecological impact of introduced crayfish on benthic fishes in a British Lowland River. Conserv Biol 11:641647. https://doi.org/10.1046/j.1523-1739.1997.96073.x

Harrington LA, Moehrenschlager A, Gelling M et al (2013) Conflicting and complementary ethics of animal welfare considerations in reintroductions. Conserv Biol 27:486-500. https://doi.org/10. 1111/cobi.12021

Hendrycks W, Abeel T, Vermeersch X et al (2014) Nociception and pain perception in noble crayfish (Astacus astacus) using the novel object paradigm

Hesselschwerdt J, Tscharner S, Necker J, Wantzen KM (2009) A local gammarid uses kairomones to avoid predation by the invasive crustaceans Dikerogammarus villosus and Orconectes limosus. Biol Invasions 11:2133-2140. https://doi.org/10.1007/ s10530-009-9492-6

Hirsch PE, Nechwatal J, Fischer P (2008) A previously undescribed set of Saprolegnia spp. in the invasive spiny-cheek crayfish (Orconectes limosus, Rafinesque). Fundam Appl Limnol 172:161-165. https://doi.org/10.1127/1863-9135/2008/ $0172-0161$

Hirvonen H (1992) Effects of backswimmer (Notonecta) predation on crayfish (Pacifastacus) young: autotomy and behavioural responses. Ann Zool Fenn 29:261-271

Holdich D, Black J (2007) The spiny-cheek crayfish, Orconectes limosus (Rafinesque, 1817) [Crustacea: Decapoda: Cambaridae], digs into the UK. Aquat Invasions 2:1-15. https://doi.org/ 10.3391/ai.2007.2.1.1

Holdich DM, Reynolds JD, Souty-Grosset C, Sibley PJ (2009a) A review of the ever increasing threat to European crayfish from 
non-indigenous crayfish species. Knowl Manag Aquat Ecosyst 2009:394-395. https://doi.org/10.1051/kmae/2009025

Holdich DM, Palmer M, Sibley PJ (2009b) The indigenous status of Austropotamobius pallipes (Lereboullet) in Britain. Atlantic 2009:1-11

Holdich DM, James J, Jackson C, Peay S (2014) The North American signal crayfish, with particular reference to its success as an invasive species in Great Britain. Ethol Ecol Evol 26:232-262. https://doi.org/10.1080/03949370.2014.903380

IUCN/SSC (2013) Guidelines for reintroductions and other conservation translocations. In: Version 1.0. IUCN species survival commission, Gland, Switzerland

Jarić I, Courchamp F, Correia RA et al (2020) The role of species charisma in biological invasions. Front Ecol Environ 18:345353. https://doi.org/10.1002/fee. 2195

Jernelöv A (2017) The long-term fate of invasive species: aliens forever or integrated immigrants with time? Springer, Dordrecht

Johnsen SI, Taugbøl T (2010) NOBANIS—invasive alien species fact sheet Pacifastacus leniusculus. In: Online Database Eur Netw Invasive Alien Species-NOBANIS. www.nobanis.org, pp 1-9

Kawai N, Kono R, Sugimoto S (2004) Avoidance learning in the crayfish (Procambarus clarkii) depends on the predatory imminence of the unconditioned stimulus: a behavior systems approach to learning in invertebrates. Behav Brain Res 150:229-237. https://doi.org/10.1016/S0166-4328(03)00261-4

Kotsyuba EP, Dyuizen IV, Lamash NE (2010) Stress induced changes in the nitric oxide system of shore crabs living under different ecological conditions. Rus J Mar Biol 36:201-208. https://doi. org/10.1134/S1063074010030065

Kouba A, Petrusek A, Kozák P (2014) Continental-wide distribution of crayfish species in Europe: update and maps. Knowl Manag Aquat Ecosyst. https://doi.org/10.1051/kmae/2014007

Krieg R, Zenker A (2020) A review of the use of physical barriers to stop the spread of non-indigenous crayfish species. Rev Fish Biol Fish. https://doi.org/10.1007/s11160-020-09606-y

Krieg R, King A, Zenker A (2021) Barriers against invasive crayfish species in natural waters and fish passes-practical experience. Glob Ecol Conserv 25:e01421. https://doi.org/10.1016/j.gecco. 2020.e01421

Law EA, Bennett NJ, Ives CD et al (2018) Equity trade-offs in conservation decision making. Conserv Biol 32:294-303. https://doi. org/10.1111/cobi.13008

Littin KE, Mellor DJ (2005) Strategic animal welfare issues: ethical and animal welfare issues arising from the killing of wildlife for disease control and environmental reasons. OIE Rev Sci Tech 24:767-782. https://doi.org/10.20506/rst.24.2.1611

Lyko F (2017) The marbled crayfish (Decapoda: Cambaridae) represents an independent new species. Zootaxa 4363:544-552. https://doi.org/10.11646/zootaxa.4363.4.6

Magee B, Elwood RW (2013) Shock avoidance by discrimination learning in the shore crab (Carcinus maenas) is consistent with a key criterion for pain. J Exper Biol 216:353-358. https://doi. org/10.1242/jeb.072041

Magee B, Elwood RW (2016) Trade-offs between predator avoidance and electric shock avoidance in hermit crabs demonstrate a non-reflexive response to noxious stimuli consistent with prediction of pain. Behav Process 130:31-35. https://doi.org/10. 1016/j.beproc. 2016.06 .017

Maldonado H, Miralto A (1982) Effect of morphine and naloxone on a defensive response of the mantis shrimp (Squilla mantis). J Comp Physiol 147:455-459. https://doi.org/10.1007/BF006 12010

Manenti R, Bonelli M, Scaccini D et al (2014) Austropotamobius pallipes reduction vs. Procambarus clarkii spreading: management implications. J Nat Conserv 22:586-591. https:// doi.org/10.1016/j.jnc.2014.09.001

Manenti R, Ghia D, Fea G et al (2019a) Causes and consequences of crayfish extinction: Stream connectivity, habitat changes, alien species and ecosystem services. Freshw Biol 64:284-293. https://doi.org/10.1111/fwb.13215

Manenti R, Barzaghi B, Tonni G, Ficetola GF, Melotto A (2019b) Even worms matter: cave habitat restoration for a planarian species increased environmental suitability but not abundance. Oryx 53(2):216-221

Mannheim SL, Childs AR, Butler EC et al (2018) Working with, not against recreational anglers: evaluating a pro-environmental behavioural strategy for improving catch-and-release behaviour. Fish Res 206:44-56. https://doi.org/10.1016/j.fishres. 2018.04.016

Maran T, Henttonen H (1995) Why is the European mink (Mustela lutreola) disappearing? A review of the process and hypotheses. Anna Zool Fenn 32:117-121

Marchina C, Natali C, Fazzini M et al (2017) Extremely dry and warm conditions in northern Italy during the year 2015: effects on the Po river water. Rend Fis Acc Lincei 28:281-290. https:// doi.org/10.1007/s12210-017-0596-0

Martin P, Dorn NJ, Kawai T et al (2010) The enigmatic Marmorkrebs (marbled crayfish) is the parthenogenetic form of Procambarus fallax (Hagen, 1870). Contrib to Zool 79:107-118. https://doi. org/10.1163/18759866-07903003

Martinati P (1861) Nota sulla malattia dei gamberi, che ammorbò le acque del veronese nel 1861. In: Memorie dell'Accademia d'Agricoltura, Commercio ed Arti di Verona XLI, pp 215-223

Martín-Torrijos L, Campos Llach M, Pou-Rovira Q, Diéguez-Uribeondo J (2017) Resistance to the crayfish plague, Aphanomyces astaci (Oomycota) in the endangered freshwater crayfish species, Austropotamobius pallipes. PLoS ONE 12:1-13. https://doi.org/10.1371/journal.pone.0181226

Mazza G, Agostini N, Aquiloni L et al (2011) The indigenous crayfish Austropotamobius pallipes complex in a national park of Central Italy. Knowl Manag Aquat Ecosyst. https://doi.org/10. $1051 / \mathrm{kmae} / 2011041$

Mazza G, Reboleira ASPS, Alves FG et al (2014) A new threat to groundwater ecosystems: First occurrences of the invasive crayfish Procambarus clarkii (Girard, 1852) in European caves. J Cave Karst Stud 76:62-65. https://doi.org/10.4311/ 2013LSC0115

Mazza G, Aquiloni L, Inghilesi AF et al (2015) Aliens just a click away: the online aquarium trade in Italy. Manag Biol Invasions 6:253-261. https://doi.org/10.3391/mbi.2015.6.3.04

McFarlane A, O’Brien J, Nelson B, Gammell M (2019) Estimating the population size of the endangered white-clawed crayfish Austropotamobius pallipes using mark-recapture at three Special Areas of Conservation (SACS). Biol Environ Proc R Ir Acad 119B(2-3):75-91. https://doi.org/10.3318/bioe.2019.08 Mepham B (1996) Food ethics. Routledge, London, New York

Mezzetto D, Dartora F, Mori E (2021) Feeding plasticity and temporal behaviour of the alien American mink in Europe. Acta Oecol 110:103700. https://doi.org/10.1016/j.actao.2020.103700

Miles C (2018) A crawfish odyssey: Procambarus clarkii as an emerging food source in Southern Spain. Southern Q 56(1):130-146

Nardi PA, Bernini F, Bo T et al (2005) Status of Austropotamobius pallipes complex in the watercourses of the Alessandria province (N-W Italy). Bull Fr la Pech la Prot des Milieux Aquat. https:// doi.org/10.1051/kmae:2005017

Ninni AP (1865) Sulla mortalità dei gamberi (Astacus fluviatilis L.) nel Veneto e più particolarmente nella provincia trevigiana. Atti Istituto Veneto Serie III-10:1203-1209 
Nonnis Marzano F, Scalici M, Chiesa S et al (2009) The first record of the marbled crayfish adds further threats to fresh waters in Italy. Aquat Invasions 4:401-404. https://doi.org/10.3391/ai.2009.4. 2.19

Pârvulescu L, Paloş C, Molnar P (2009) First record of the spinycheek crayfish Orconectes limosus (Rafinesque, 1817) (Crustacea: Decapoda: Cambaridae) in Romania. North West J Zool 5:424-428

Patoka J, Petrtýl M, Kalous L (2014) Garden ponds as potential introduction pathway of ornamental crayfish. Knowl Manag Aquat Ecosyst. https://doi.org/10.1051/kmae/2014019

Patoka J, Magalhães ALB, Kouba A, Faulkes Z, Jerikho R, Vitule JRS (2018) Invasive aquatic pets: Failed policies increase risks of harmful invasions. Biodivers Conserv 27:3037-3046. https://doi. org/10.1007/s10531-018-1581-3

Peay S (2009) Invasive non-indigenous crayfish species in Europe: recommendations on managing them. Knowl Manag Aquat Ecosyst. https://doi.org/10.1051/kmae/2010009

Peay S, Johnsen SI, Bean CW et al (2019) Biocide treatment of invasive signal crayfish: successes, failures and lessons learned. Diversity. https://doi.org/10.3390/d11030029

Pretty J, Adams B, Berkes F et al (2009) The intersections of biological diversity and cultural diversity: towards integration. Conserv Soc 7:100-112. https://doi.org/10.4103/0972-4923.58642

Puri S, Faulkes Z (2010) Do decapod crustaceans have nociceptors for extreme $\mathrm{pH}$ ? PLoS ONE 5:e10244. https://doi.org/10.1371/ journal.pone.0010244

Puri S, Faulkes Z (2015) Can crayfish take the heat? Procambarus clarkii show nociceptive behaviour to high temperature stimuli, but not low temperature or chemical stimuli. Biol Open 4:441448. https://doi.org/10.1242/bio.20149654

Renai B, Gherardi F (2004) Predatory efficiency of crayfish: comparison between indigenous and non-indigenous species. Biol Invasions 6:89-99. https://doi.org/10.1023/B:BINV.0000010126. 94675.50

Renai B, Bertocchi S, Brusconi S et al (2006) Ecological characterisation of streams in Tuscany (Italy) for the management of the threatened crayfish Austropotamobius pallipes complex. Bull Fr la Pech la Prot des Milieux Aquat. https://doi.org/10.1051/kmae: 2006013

Reynolds JD (2011) A review of ecological interactions between crayfish and fish, indigenous and introduced. Knowl Manag Aquat Ecosyst. https://doi.org/10.1051/kmae/2011024

Rodríguez CF, Bécares E, Fernández-Aláez M, Fernández-Aláez C (2005) Loss of diversity and degradation of wetlands as a result of introducing exotic crayfish. Biol Invasions 7(1):75-85. https:// doi.org/10.1007/1-4020-3870-4_7

Rodríguez-Estival J, Morales-Machuca C, Pareja-Carrera J, OrtizSantaliestra ME, Mateo R (2019) Food safety risk assessment of metal pollution in crayfish from two historical mining areas: Accounting for bioavailability and cooking extractability.
Ecotoxicol Environ Saf 185:109682. https://doi.org/10.1016/j. ecoenv.2019.109682

Rosenblatt RA (2005) Ecological change and the future of the human species: can physicians make a difference? Ann Family Med 3(2):173-176. https://doi.org/10.1370/afm.271

Scalici M, Gibertini G (2005) Can Ausropotamobius italicus meridionalis be used as a monitoring instument in cental Italy? Bull Fr la Pech la Prot des Milieux Aquat 376:613-625. https://doi.org/ 10.1051/KMAE:2005019

Scalici M, Pitzalis M, Gibertini G (2009) Crayfish distribution updating in central Italy. Knowl Manag Aquat Ecosyst. https://doi.org/10. 1051/kmae/2009017

Scholtz G, Braband A, Tolley L, Reimann A, Mittmann B, Lukhaup C, Steuerwald F, Vogt G (2003) Parthenogenesis in an outsider crayfish. Nature 421:806. https://doi.org/10.1038/421806a

Schuster GA, Taylor CA, Cordeiro J (2010) Pacifastacus leniusculus, signal crayfish. IUCN Red List Threat Species 2010 e.T153648A4526314. https://doi.org/10.2305/IUCN.UK.20103.RLTS.T153648A4526314.en

Smal CM (1991) Population studies on feral American mink Mustela vison in Ireland. J Zool 224:233-249. https://doi.org/10.1111/j. 1469-7998.1991.tb04802.x

Souty Grosset C, Holdich DM, Noël P, Reynolds JD, Haffner P (2006) Atlas of crayfish in Europe. In: Muséum National d'Histoire Naturelle, Paris

Souty-Grosset C, Anastácio PM, Aquiloni L et al (2016) The red swamp crayfish Procambarus clarkii in Europe: impacts on aquatic ecosystems and human well-being. Limnologica 58:7893. https://doi.org/10.1016/j.limno.2016.03.003

Strayer DL, Dudgeon D (2010) Freshwater biodiversity conservation: recent progress and future challenges. J N Am Benthol Soc 29:344-358. https://doi.org/10.1899/08-171.1

Svoboda J, Mrugała A, Kozubíková-Balcarová E, Petrusek A (2017) Hosts and transmission of the crayfish plague pathogen Aphanomyces astaci: a review. J Fish Dis 40-1:127-140. https://doi.org/ $10.1111 /$ jfd. 12472

Tirelli T, Mussat Sartor R, Bona F et al (2008) Census of Austropotamibius genus in four district of Piedmont. Boll del Mus Reg di Sci Nat di Torino 25:595-608

Tricarico E, Vilizzi L, Gherardi F, Copp GH (2010) Calibration of FI-ISK, an invasiveness screening tool for nonnative freshwater invertebrates. Risk Anal 30:285-292. https://doi.org/10.1111/j. 1539-6924.2009.01255.x

Wittmann A, Flores-Ferrer A (2015) Analyse économique des espèces exotiques envahissantes en France Première enquête nationale (2009-2013). Commis général au développement durable. Études Documents 130:1-132

Publisher's Note Springer Nature remains neutral with regard to jurisdictional claims in published maps and institutional affiliations. 